\title{
Dietary Patterns and Breast Cancer Risk: A Systematic Review
}

\author{
AKHILA DANDAMUDI, JESSIE TOMMIE, LAURIE NOMMSEN-RIVERS and SARAH COUCH \\ College of Allied Health Sciences, University of Cincinnati, Cincinnati, OH, U.S.A.
}

\begin{abstract}
Background/Aim: The association of dietary patterns representing multiple dietary components and breast cancer risk is not clearly understood. Our objective was to conduct a systematic review of the association between dietary patterns and breast cancer risk. Materials and Methods: The original articles included, were published between January 2013 and May 2017 and characterized diets using a priori and posteriori approaches to examine associations between dietary patterns and breast cancer risk. A novel scoring matrix was used to grade posteriori dietary pattern alignment with the American Cancer Society dietary guidelines. Results: Seventeen case-control and nested case-control studies identified 15 healthy, and 10 unhealthy, dietary patterns determined posteriori, and 7 dietary indices determined a priori. Vegetables were consistently found in breast cancer protective patterns whereas saturated fat and red and processed meats were consistently found in patterns associated with increased breast cancer risk. Conclusion: Findings suggest that dietary patterns that include vegetables and limit saturated fat and red and processed meats may lower breast cancer risk.
\end{abstract}

Breast cancer is the second leading cause of cancer-related deaths in women (1) and the most common cancer among women worldwide (2). The modifiable risk factors for breast cancer include alcohol intake, excess adiposity, physical inactivity and poor diet (3-5). Early empirical evidence regarding diet and breast cancer focused predominately on single nutrients and individual's foods or food components to identify associations (6-9). However, more recent evidence points to the complexity of the diet and the notion

This article is freely accessible online.

Correspondence to: Akhila Dandamudi, College of Allied Health Sciences, University of Cincinnati, 3202 Eden Avenue, Cincinnati, OH, U.S.A. Tel: +1 5135587503, e-mail: dandamaa@mail.uc.edu

Key Words: Diet, dietary patterns, breast cancer, American Cancer Society, statistical analyses, review. that food and nutrients are not consumed in isolation and often work synergistically (10-12).

The recognition of food and nutrient interactions within the diet in relation to health risk has led to a shift in nutrition research towards a more holistic approach to dietary assessment. In this context, in the more recent literature, emphasis has been placed on assessing dietary patterns rather than individual foods or nutrients to better understand the way people eat, as it relates to health risk. A meta-analysis of prospective studies published up to December 2015 by Wu et al. (12) showed that dietary patterns that emphasized intake of soy and skim milk were associated with a lower risk of breast cancer while patterns that emphasized intake of total, red and processed meats were associated with higher risk of breast cancer.

Newer guidelines have followed suit making recommendations based on food patterns rather than individual foods and nutrients to modify health risks. For example, the American Cancer Society recommends eating a healthy diet with an emphasis on plant foods to reduce a person's lifetime risk of developing cancer (13).

Most approaches used to characterize dietary patterns can be classified as either posteriori or a priori (14). Posteriori approaches apply multivariate statistical methods such as principal component analysis, factor analysis and cluster analysis directly to a participant's food data collected by food frequency questionnaire (FFQ), dietary recall, or food record to derive the dietary patterns (15). A priori/ approaches score an individual's actual intake as compared against an established dietary index, such as the Healthy Eating Index (16).

The World Cancer Research Fund report published in 2007 showed that, while a high alcohol intake was associated with high risk of breast cancer, the associations between breast cancer risk and different dietary patterns were inconclusive (17). Since then, two systematic reviews published in 2010 and 2013 evaluated 16 and 26 studies, respectively, to understand the effect of posteriori derived dietary patterns on risk of breast cancer $(18,19)$. These analyses showed that there is a small inverse association between a healthy dietary pattern and breast 
cancer risk, and a positive association between alcohol and breast cancer risk. A limitation of these studies was that they did not base their characterization of healthy dietary patterns on established guidelines for reducing breast cancer risk. Additionally, these reviews did not include studies of dietary patterns that were determined a priori. There have been several posteriori and a priori studies conducted since the last systematic review in 2013 and hence, there is a need for a more comprehensive review on this topic. The purpose of the present study was to systematically evaluate the literature published since 2013 on dietary patterns and breast cancer risk that characterized diets using a priori and posteriori approaches to gain a better understanding of the association between healthy and unhealthy dietary patterns and breast cancer risk.

\section{Materials and Methods}

Search strategy. The studies included in this systematic review were selected from PubMed and EMBASE databases. The keywords or phrases used to perform the search were 'diet', 'dietary patterns', 'breast neoplasms', 'breast cancer' and 'breast tumor'. The electronic search was restricted to 'female breast cancer studies in humans' reported in English language between January 2013 and May 2017. All the search results were pooled, and duplicate studies were removed by the first author. Also, we hand searched the cited references of included studies for additional relevant studies. Data is reported in accordance with PRISMA guidelines (20).

Inclusion and exclusion criteria. Only original studies that examined the association between a combination of multiple food and nutrient related dietary components or dietary patterns with the risk of breast cancer were included in this review. To be included, studies must have reported the risk estimates of breast cancer by comparing the highest to the lowest categories of dietary intake (Hazards ratio [HR], Odds ratio [OR] or Relative Risk ratio [RR]) and measures of variability ( $95 \%$ confidence interval $(\mathrm{CI})$ or standard error). Additionally, diet quality scores referenced in a priori studies must have used established national or regional dietary guidelines as their basis. Studies included in this review examined the relationship between diet and primary breast cancer risk; studies which examined breast cancer survival, recurrence, or metastasis were excluded. Articles that described only meal intake patterns such as the number of meals, frequency of eating, or intake of macronutrients alone were excluded as they did not contribute to defining a dietary pattern. Studies that collected the dietary data of women during their childhood or adolescence were excluded to ensure that only adult dietary intakes were considered for determination of dietary patterns.

Data extraction. The information that was abstracted from each of the articles that used a posteriori approach included: author name, year of publication, location of data collection, study design, cohort or participant source, sample size and participant characteristics, dietary assessment method and characteristics (e.g. number of questions on FFQs, method of administration, period of assessment), and, dietary pattern identification method (Table I). Studies that used an a priori approach in determining dietary patterns abstracted the same parameters listed for the posteriori analysis except the dietary pattern identification method was replaced by the dietary pattern index range (Table II).
Assessment of exposure. Determination of healthy and unhealthy dietary patterns: The first author (AD) and fourth author (SCC) derived a scoring matrix to quantify the extent to which the published dietary patterns aligned with dietary recommendations established by the American Cancer Society (ACS) as cancer protective or promoting (13). For a given dietary pattern, +1 point was awarded each time one of the six ACA-designated healthy (cancer protective) food groups such as vegetables (including starchy vegetables), fruits, legumes and lentils (includes soy and tofu), lean protein (fish, poultry, low-fat dairy), whole grains, nuts and seeds were represented in the explanation of the dietary pattern. A - 1 point was assigned each time one of the six ACAdesignated unhealthy (cancer promoting) food groups that include sugar sweetened beverages and candy, saturated fat (butter, mayonnaise), red and processed meats including organ meat, fried and fast foods, refined grains (white rice, white bread, white pasta, cookies, cakes, breakfast cereal and snacks) and alcohol were represented in the explanation of the dietary pattern. Pattern scores were then summed, which could range from a maximum score of +6 for the strongest representation of the ACA healthy food groups to a minimum score of -6 for the strongest representation of the ACA unhealthy food groups. For the purposes of this review, dietary patterns that had an overall score of +2 or higher were considered 'healthy' while dietary patterns with an overall score of -2 or lower were considered 'unhealthy'. Dietary patterns that received a score of $-1,0$ or 1 were excluded from further analysis.

Star rating of exposure: 4-star rating criteria were developed for the included studies to evaluate the quality of the dietary intake assessment method used. One star was awarded for each of the following: 1) Use of a dietary assessment measure validated for the population being assessed, 2) Use of a reproducible dietary assessment measure, 3) Use of factor loadings $\geq 0.3$ for the posteriori approach and use of a validated, quantitative, dietary scoring index for the a priori approach, and 4) Use of multiple time points of dietary data collection.

Bias. The studies were evaluated for selection bias, dietary intake recall bias and confounding. To evaluate selection bias, the criteria were examined for selecting controls in the case-control and nested case-control studies. Age, geographical location, history of cancer, menopausal status and energy intake were considered as key factors in matching controls to cases, as these factors have shown to increase or decrease the risk of developing breast cancer among women (21, 22). The reporting of dietary intake might be influenced by disease status (23). For example, women who have just received a breast cancer diagnosis may be more biased toward remembering the unhealthier aspects of their diets rather than healthier aspects. Also, treatments for cancer may dramatically disrupt the usual dietary pattern of cases. Thus, we examined the temporal window of dietary data collection and recollection relative to breast cancer diagnosis in cases. To assess the potential impact of confounding on the reported result for each analysis, we examined if the final models were adjusted or stratified for five key variables that are shown to be associated with both dietary intake and risk of breast cancer: age, physical activity, body mass index, smoking status and alcohol intake.

\section{Results}

Literature search. The PRISMA flow diagram is shown in Figure 1. The initial search resulted in 136 articles, of which 102 articles were excluded at the title and abstract level. Thirty-four full-length articles were selected for further evaluation and 18 of these were excluded for the following 
Table I. Characteristics of epidemiological studies that met inclusion criteria and used in a posteriori approach.

\begin{tabular}{|c|c|c|c|c|}
\hline $\begin{array}{l}\text { Reference, Year, } \\
\text { Location of study }\end{array}$ & $\begin{array}{l}\text { Cohort or participant } \\
\text { source }\end{array}$ & $\begin{array}{l}\text { Sample size and } \\
\text { study design }\end{array}$ & $\begin{array}{l}\text { Dietary assessment method } \\
\text { and characteristics }\end{array}$ & $\begin{array}{l}\text { Dietary pattern } \\
\text { identification method }\end{array}$ \\
\hline $\begin{array}{l}\text { Castello et al. } \\
\text { (2014), Spain }\end{array}$ & $\begin{array}{l}\text { Oncology Departments of } 23 \text { hospital } \\
\text { members of the Spanish Breast Cancer } \\
\text { Research Group, GEICAM }\end{array}$ & $\begin{array}{l}1,017 \text { cases and } \\
1,017 \text { controls; } \mathrm{CC}\end{array}$ & $\begin{array}{l}\text { Willett FFQ -117 items (26FG), } \\
\text { semi-quantitative, past } 5 \text { years, SA }\end{array}$ & PCA, no rotation \\
\hline $\begin{array}{l}\text { Catsburg et al. } \\
(2015), \text { Canada }\end{array}$ & $\begin{array}{l}\text { Canadian Study of Diet, Lifestyle } \\
\text { and Health (CSDLH) and National } \\
\text { Breast Screening Study (NBSS) }\end{array}$ & $\begin{array}{c}\text { 3,320 women in } \\
\text { CSDLH (1097 cases); } \\
\text { NCCS }\end{array}$ & $\begin{array}{l}\text { FFQ-166 items ( } 7 \text { FG), semi- } \\
\text { quantitative, past } 1 \text { year, SA }\end{array}$ & $\begin{array}{l}\text { PCFA, scree test, } \\
\text { promax rotation, } \\
\text { confirmatory factor } \\
\text { analysis done in NBSS }\end{array}$ \\
\hline $\begin{array}{l}\text { Jordan et al. } \\
\text { (2013), Tanzania }\end{array}$ & Kilimanjaro Region & $\begin{array}{c}115 \text { cases and } \\
230 \text { controls; } \text { CCS }\end{array}$ & $\begin{array}{c}\text { FFQ-65 items (36 FG), } \\
\text { semi-quantitative, IA }\end{array}$ & $\begin{array}{l}\text { PCA, EIG }>1 \text {, scree test, } \\
\text { varimax rotation }\end{array}$ \\
\hline $\begin{array}{l}\text { Karimi et al. } \\
\text { (2013), Iran }\end{array}$ & $\begin{array}{l}\text { Shohada Teaching } \\
\text { Hospital, Tehran }\end{array}$ & $\begin{array}{l}100 \text { cases and } \\
174 \text { controls; } \text { CCS }\end{array}$ & $\begin{array}{l}\text { Tehran Lipid and Glucose study } \\
\text { FFQ - } 168 \text { items ( } 26 \text { FG), semi- } \\
\text { quantitative, past } 1 \text { year, IA }\end{array}$ & PCFA, varimax rotation \\
\hline $\begin{array}{l}\text { Kojima et al. } \\
\text { (2017), Japan }\end{array}$ & $\begin{array}{l}\text { Japan Collaborative } \\
\text { Cohort study }\end{array}$ & $\begin{array}{l}23,172 \text { women }(119 \\
\text { cases); NCCS }\end{array}$ & $\begin{array}{c}\text { FFQ-39 items, semi-quantitative, } \\
\text { past } 1 \text { year, SA }\end{array}$ & $\begin{array}{l}\text { FA, EIG }>1, \text { scree plot } \\
\text { and interpretability, } \\
\text { varimax rotation }\end{array}$ \\
\hline $\begin{array}{l}\text { Link et al. } \\
(2013), \text { USA }\end{array}$ & $\begin{array}{c}\text { California Teachers } \\
\text { Study }\end{array}$ & $\begin{array}{l}91,779 \text { women }(4,140 \\
\text { cases); NCCS }\end{array}$ & $\begin{array}{l}\text { Early version of } 1995 \text { block } \\
\text { FFQ-103 items, past } 1 \text { year, SA }\end{array}$ & $\begin{array}{c}\text { PCFA, EIG }>1, \text { scree } \\
\text { plot and interpretability, } \\
\text { promax rotation }\end{array}$ \\
\hline $\begin{array}{l}\text { Mourouti et al. } \\
\text { (2015), Greece }\end{array}$ & $\begin{array}{c}\text { Pathology-oncology clinics } \\
\text { of } 5 \text { major General Hospitals } \\
\text { in Athens, Greece }\end{array}$ & $\begin{array}{c}250 \text { cases and } \\
250 \text { controls; } \text { CCS }\end{array}$ & $\begin{array}{c}\text { FFQ -86 items (14 FG), } \\
\text { semi-quantitative, past } 1 \text { year, IA }\end{array}$ & $\begin{array}{l}\text { PCFA, scree test, } \\
\text { varimax rotation }\end{array}$ \\
\hline $\begin{array}{l}\text { Pot } e t \text { al. } \\
\text { (2014), UK }\end{array}$ & $\begin{array}{l}\text { UK Dietary Cohort Consortium } \\
\text { - } 4 \text { cohorts: EPIC Norfolk, } \\
\text { EPIC Oxford, UK Women's } \\
\text { Cohort Study, Whitehall II Study }\end{array}$ & $\begin{array}{l}610 \text { cases (409 post- } \\
\text { menopausal) and } 1,891 \\
\text { controls; NCCS }\end{array}$ & $\begin{array}{l}\text { Food diaries over } 4-7 \text { days } \\
(42 \mathrm{FG}) \text {, semi-quantitative }\end{array}$ & $\begin{array}{l}\text { FA, EIG, scree plots, } \\
\text { varimax rotation }\end{array}$ \\
\hline $\begin{array}{l}\text { Ryswyk et al. } \\
\text { (2016), Canada }\end{array}$ & $\begin{array}{l}\text { Canadian National Enhanced } \\
\text { Cancer Surveillance System }\end{array}$ & $\begin{array}{l}2,009 \text { cases and } 2,086 \\
\text { controls; CCS }\end{array}$ & $\begin{array}{c}\text { FFQ (Block FFQ-modified } \\
\text { using Willett questionnaire)- } \\
69 \text { items, semi-quantitative, } \\
\text { past } 2 \text { years, SA }\end{array}$ & $\begin{array}{l}\text { PCFA, EIG }>3 \text {, scree plot } \\
\text { and interpretability, } \\
\text { varimax rotation }\end{array}$ \\
\hline $\begin{array}{l}\text { Shin et al. } \\
\text { (2016), Japan }\end{array}$ & $\begin{array}{c}\text { Japan Public Health } \\
\text { Center-based Prospective study }\end{array}$ & $\begin{array}{l}49,552 \text { women }(718 \\
\text { cases); NCCS }\end{array}$ & $\begin{array}{l}\text { FFQ-147 items ( } 48 \mathrm{FG}) \text {, semi- } \\
\text { quantitative, past } 1 \text { year, SA }\end{array}$ & $\begin{array}{l}\text { PCA, EIG }>1.75 \text {, scree } \\
\text { test, varimax rotation }\end{array}$ \\
\hline $\begin{array}{l}\text { Tiznobeyk et al. } \\
\text { (2016), Iran }\end{array}$ & $\begin{array}{l}\text { Iranian Center for Breast Cancer } \\
\text { affiliated with Academic Center } \\
\text { of Education, Culture } \\
\text { and Research, Tehran }\end{array}$ & $\begin{array}{c}96 \text { cases and } \\
70 \text { controls; CCS }\end{array}$ & $\begin{array}{c}\text { FFQ (from Tehran Lipid and } \\
\text { Glucose study)-168 items ( } 25 \mathrm{FG} \text { ), } \\
\text { semi-quantitative, past } 1 \text { year, IA }\end{array}$ & PCFA \\
\hline $\begin{array}{l}\text { Tumas et al. } \\
\text { (2014), Argentina }\end{array}$ & Cordoba population & $\begin{array}{l}100 \text { cases and } 294 \\
\text { controls; } \text { CCS }\end{array}$ & $\begin{array}{c}\text { FFQ-127 items }(20 \mathrm{FG}), \\
\text { Semi-quantitative, } \\
\text { previous } 5 \text { years, IA }\end{array}$ & $\begin{array}{c}\mathrm{FA}, \mathrm{EIG}>1 \\
\text { varimax rotation }\end{array}$ \\
\hline $\begin{array}{l}\text { Wu et al. } \\
\text { (2013), Taiwan }\end{array}$ & $\begin{array}{c}\text { Buddhist Tzu Chi } \\
\text { General Hospital, Taipei }\end{array}$ & $\begin{array}{l}98 \text { cases and } 103 \\
\text { controls; CCS }\end{array}$ & $\begin{array}{l}\text { FFQ (adopted from Nutritional } \\
\text { and Health Survey in Taiwan) } \\
-43 \text { items, past } 1 \text { year, IA }\end{array}$ & $\begin{array}{c}\text { PCA, EIG }>1.5 \text { scree } \\
\text { plot and interpretability, } \\
\text { varimax rotation }\end{array}$ \\
\hline
\end{tabular}

CCS: Case-control study; NCCS: nested case-control study; FFQ: food frequency questionnaire; FG: food groups; SA: self-administered; IA: interviewer administered; PCA: principal component analysis; PCFA: principal component factor analysis; FA: factor analysis; DP: dietary pattern; OR: odds ratio; RR: relative risk; HR: hazards ratio, CI: confidence interval; EIG: eigen value; BMI: body mass index; BC: breast cancer.

reasons: examined diet as a predictor of breast density not cancer $(n=3)(24-26)$, the combined effect of diet and physical activity was studied $(n=2)(27,28)$, statistical methods other than those specified in our inclusion criteria were used $(n=2)(29,30)$, and evaluated various forms of vegetarian diet (derived without using any dietary index or factor analysis) $(n=1)(31)$, hormone levels rather than diet were studied $(n=3)(32-34)$, the effect of diet on breast cancer markers at the molecular level were studied $(n=5)$ (35-39), assessed the dietary intake of women during their adolescent years $(n=1)(40)$, used an average/reference dietary pattern to derive the risk estimates $(n=1)(41)$, one paper was identified by hand searching the selected articles (42). This resulted in the selection of 17 original research studies published between January 2013 and May 2017 (4258 ), where 13 of these used the posteriori approach while 2 
Table II. Characteristics of epidemiological studies that met the inclusion criteria and used a priori approach.

\begin{tabular}{|c|c|c|c|c|}
\hline $\begin{array}{l}\text { Reference, Year, } \\
\text { Location of study }\end{array}$ & $\begin{array}{c}\text { Cohort or participant } \\
\text { source }\end{array}$ & $\begin{array}{l}\text { Sample size and } \\
\text { participant characteristics }\end{array}$ & $\begin{array}{l}\text { Dietary assessment method } \\
\text { and characteristics }\end{array}$ & $\begin{array}{l}\text { Dietary pattern index range } \\
\text { (higher values indicate } \\
\text { greater adherence) }\end{array}$ \\
\hline $\begin{array}{l}\text { Castello et al. } \\
\text { (2014), Spain }\end{array}$ & $\begin{array}{c}\text { Oncology Departments of } 23 \\
\text { hospital members of the Spanish } \\
\text { Breast Cancer Research Group, } \\
\text { GEICAM }\end{array}$ & $\begin{array}{l}1,017 \text { cases and } 1,017 \\
\quad \text { controls; } \mathrm{CCS}\end{array}$ & $\begin{array}{l}\text { Willett FFQ }-117 \text { items } \\
(26 \mathrm{FG}), \text { semi-quantitative, } \\
\text { past } 5 \text { years, SA }\end{array}$ & $\begin{array}{c}\text { Alternate Healthy } \\
\text { Eating Index (AHEI) } \\
(0-75) \\
\text { Alternate Mediterranean } \\
\text { Diet Score (aMED) } \\
\text { (0-8 after excluding alcohol) }\end{array}$ \\
\hline $\begin{array}{l}\text { Couto et al. } \\
\text { (2013), Sweden }\end{array}$ & $\begin{array}{l}\text { Swedish Women's Lifestyle } \\
\text { and Health cohort study }\end{array}$ & $\begin{array}{c}\text { 49, } 258 \text { women }(1,278 \\
\text { cases); NCCS }\end{array}$ & $\begin{array}{l}\text { FFQ-80 items, semi- } \\
\text { quantitative, past } \\
6 \text { months, SA }\end{array}$ & $\begin{array}{l}\text { Mediterranean Diet Score } \\
\text { (MDS, defined by } \\
\text { Trichopoulou et al. (16)) (0-9 }\end{array}$ \\
\hline $\begin{array}{l}\text { Li } \text { et al. } \\
\text { (2015), Sweden }\end{array}$ & $\begin{array}{l}\text { Norwegian-Swedish } \\
\text { women's lifestyle and } \\
\text { Health Cohort Study }\end{array}$ & $\begin{array}{c}44,296 \text { women } \\
\text { (1,464 cases); NCCS }\end{array}$ & $\begin{array}{l}\text { FFQ-80 items, past } \\
6 \text { months, SA }\end{array}$ & $\begin{array}{l}\text { Healthy Nordic Food } \\
\text { Index (HFNI) }(0-6)\end{array}$ \\
\hline $\begin{array}{l}\text { Morouti et al. } \\
\text { (2014), Greece }\end{array}$ & $\begin{array}{l}\text { Pathology-oncology clinics } \\
\text { of } 5 \text { major General } \\
\text { Hospitals in Athens, Greece }\end{array}$ & $\begin{array}{l}250 \text { cases and } 250 \\
\text { controls; CCS }\end{array}$ & $\begin{array}{l}\text { FFQ-86 items, semi- } \\
\text { quantitative, past } 1 \text { year, IA }\end{array}$ & MedDietScore (0-55) \\
\hline $\begin{array}{l}\text { Pot et al. } \\
\text { (2014), UK }\end{array}$ & $\begin{array}{c}\text { UK Dietary Cohort } \\
\text { Consortium - } 4 \text { cohorts: } \\
\text { EPIC Norfolk, EPIC Oxford, } \\
\text { UK Women's Cohort Study, } \\
\text { Whitehall II Study }\end{array}$ & $\begin{array}{c}610 \text { cases ( } 409 \text { post- } \\
\text { menopausal) and } 1,891 \\
\text { controls; NCCS }\end{array}$ & $\begin{array}{l}\text { Food diaries over 4-7 days } \\
\text { (42 FG), semi-quantitative }\end{array}$ & $\begin{array}{l}\text { Mediterranean Diet Score } \\
\text { (MDS, defined by } \\
\text { Trichopoulou } \text { et al. }(16)) \\
\text { (0-8 when excluding alcohol) }\end{array}$ \\
\hline $\begin{array}{l}\text { Shahril et al. } \\
\text { (2013), Malaysia }\end{array}$ & $\begin{array}{c}\text { Kuala Lumpur, } \\
\text { Malaysia }\end{array}$ & $\begin{array}{c}382 \text { cases and } \\
382 \text { controls; } \text { CCS }\end{array}$ & $\begin{array}{c}\text { FFQ - } 200 \text { items, semi- } \\
\text { quantitative, past } 1 \text { year, IA }\end{array}$ & $\begin{array}{l}\text { Healthy Eating Index } \\
\text { (2005) (HEI-2005) }\end{array}$ \\
\hline
\end{tabular}

CCS: Case-control study; NCCS: nested case-control study; FFQ: food frequency questionnaire; FG: food groups; SA: self-administered; IA: interviewer administered; OR: odds ratio; RR: relative risk; HR: hazards ratio, CI: confidence interval; BMI: body mass index; BC: breast cancer.

of the 13 also included an a priori approach to identify dietary patterns. Four studies exclusively used the a priori approach resulting in a total of 6 studies that used the $a$ priori approach for the identification of dietary patterns.

Assessment of exposure. Determination of dietary patterns: The composition of dietary patterns and their classification (healthy, unhealthy, or excluded) using the ACS-derived scoring matrix are shown in Table III. The median score of the healthy dietary patterns was 3.5 (range $=2$ to 5 points) while the median score of the unhealthy dietary patterns was -3.5 (range $=-2$ to -4 points). The ACS-derived classification of healthy and unhealthy dietary patterns was consistent with diet patterns identified in posteriori analysis by Castello et al. (50), Karimi et al. (47), Mourouti et al. (52), Ryswyk et al. (57), Shin et al. (54), and Tiznobeyk et al. (55). These authors named their healthy dietary patterns as "healthy" or "prudent" with scores that ranged from 2 to 5 and named their unhealthy dietary patterns as "western" or "unhealthy" with scores that equaled -4 . While several dietary patterns were identified by Catsburg et al. (44), Kojima et al. (48), and Pot et al. (53) only the "healthy" dietary pattern was included from Catsburg et al. (44), the "vegetable" dietary pattern from Kojima et al. (48), and the "first" dietary pattern from Pot et al. (53), as these patterns received a score of +2 or higher. Out of the five dietary patterns identified by Jordan et al. (46), two dietary patterns received a score of +2 and were included as healthy patterns in these analyses, while the "fatty diet", which scored -2 , was classified as unhealthy. The dietary pattern named "plant-based" by Link et al. (50) was classified in the healthy category while the patterns identified as "high-carbohydrate" and "high-protein, high-fat" were classified as unhealthy. The "prudent" dietary pattern identified by Tumas et al. (56) and the "picklevegetable" dietary pattern by Wu et al. (58) fell under the healthy category while the "traditional dietary pattern" by Tumas et al. (56) and the "sugar-fried food" dietary pattern by $\mathrm{Wu}$ et al. (58) fell under the unhealthy category. In total, of the thirteen studies that used posteriori approach to dietary pattern characterization, all thirteen identified at least one healthy dietary pattern; two identified two healthy patterns. Nine of the thirteen identified at least one unhealthy dietary pattern; one study identified two unhealthy dietary patterns. The seventeen patterns that did not meet the healthy or unhealthy score cut-off are also shown in Table III. The nomenclature used to characterize the "healthy" and unhealthy dietary patterns in the original research papers can also be found in Table III. 


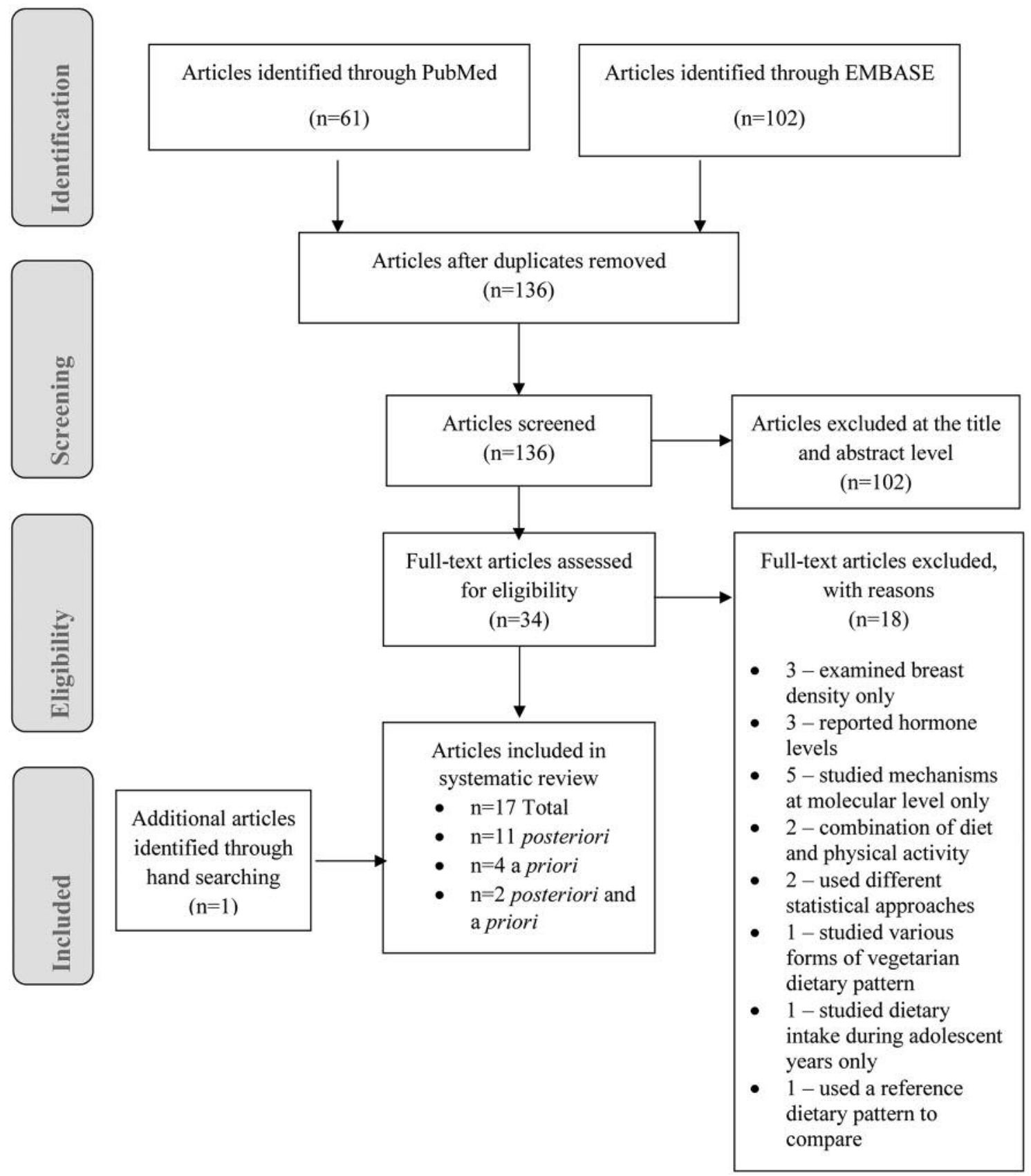

Figure 1. PRISMA Flow diagram for selection of published research articles.

Assessment of outcome. The outcomes of the included studies are evaluated below and the risk estimates are depicted in the forest plots shown in Figures 2-4. Table IV and $\mathrm{V}$ are summary tables that show foods, identified by the ACS cancer prevention dietary guidelines as cancer protective (Table IV) and cancer promoting (Table V), that were common to the healthy and unhealthy dietary patterns included in these analyses. Results are summarized below.
Posteriori/Exploratory approach: Healthy dietary pattern. Thirteen studies (five nested case-control studies and eight case-control studies) characterizing 15 healthy dietary patterns evaluated the association of dietary pattern and breast cancer risk (Figure 2). Notably, one study by Kojima et al. (48) examined this relationship separately in pre- and post-menopausal women, while the others assessed all adult women regardless of menopausal status. A total of fifteen 
Table III. Characteristics of dietary patterns of studies meeting the inclusion criteria and their component foods and American Cancer Society (ACS)-derived diet quality scores (in parentheses).

\begin{tabular}{|c|c|}
\hline Reference & Dietary pattern and component foods and ACS-derived quality scores \\
\hline Castello et al. & $\begin{array}{l}\text { Healthy: Prudent (4)- low-fat dairy products, vegetables, fruits, whole grains and juices; Mediterranean (4)- } \\
\text { fish, vegetables, legumes, boiled potatoes, fruits, olives and vegetable oil } \\
\text { Unhealthy: Western (-4)- high-fat dairy, processed meat, refined grains, sweets, caloric drinks and } \\
\text { other convenience food and sauces } \\
\text { Other: None }\end{array}$ \\
\hline Catsburg et al. & $\begin{array}{l}\text { Healthy: Healthy (2)- vegetable and legume food groups } \\
\text { Unhealthy: None } \\
\text { Other: Traditional/Ethnic }(0) \text { - rice, spinach, fish, tofu, liver, eggs, and salted and dried meat; } \\
\text { Meat and potatoes }(0) \text { - red meat groups and potatoes }\end{array}$ \\
\hline Jordan et al. & $\begin{array}{l}\text { Healthy: Fruity Diet (2)- fish, mango, papaya, avocado and watery fruits; Mchicha (2)- mchicha (amaranth leaf), } \\
\text { cucumber, okra, onions, carrots, tomatoes, maize, fish and avocado } \\
\text { Unhealthy: Fatty Diet (-2)- milk, vegetable oils and fats, butter, lard and red meat } \\
\text { Other: Diet of the rich (0)- rice, nuts, eggs, chapatti (unleavened East African flat wheat bread), } \\
\text { leguminous vegetables, bread, soda and red meat; Banana leaf (1)- ripe and green banana, sugar, } \\
\text { different fruits, tubers, pulses and Mbege (local, often homemade opaque beer from bananas and millet) }\end{array}$ \\
\hline Karimi et al. & $\begin{array}{l}\text { Healthy: Healthy (5)- vegetables, fruits, low-fat dairy products, legumes, olive and vegetable oils, } \\
\text { fish, condiments, organ meat, poultry, pickles, soya and whole grains } \\
\text { Unhealthy: Unhealthy (-4)- soft drinks, sugars, tea and coffee, French fries and potato chips, salt, } \\
\text { sweets and desserts, hydrogenated fats, nuts, industrial juice, refined grains, and red and processed meat }\end{array}$ \\
\hline Kojima et al. & $\begin{array}{l}\text { Healthy: Vegetable pattern (4)- vegetables, potatoes, seaweed, tofu, fruits, fresh fish, eggs, and miso soup } \\
\text { Unhealthy: None } \\
\text { Other: Dairy product pattern (1)- milk, dairy products, fruits, coffee and tea; Animal food pattern } \\
\text { (-1)- meat, deep-fried foods, fried vegetables, fish paste and salt, preserved fish }\end{array}$ \\
\hline Link et al. & $\begin{array}{l}\text { Healthy: Plant-based (2)- fruit and vegetables } \\
\text { Unhealthy: High-carbohydrate (-2)- convenience foods, pasta, butter, and bread; High-Protein, } \\
\text { high fat (-2)- animal protein (e.g. meat and eggs) and added fats } \\
\text { Other: Salad and wine pattern (1)- salad and low-fat dressing, fish, wine, and coffee and tea; } \\
\text { Ethnic pattern (1)- legumes, soy-based foods, rice, and vegetables }\end{array}$ \\
\hline Mourouti et al. & $\begin{array}{l}\text { Healthy: Healthy (3)- whole grains, fruits, vegetables } \\
\text { Unhealthy: None } \\
\text { Other: Mediterranean (1)-Fish, olive oil in cooking; Unhealthy (-1)- potatoes, red meat and products, } \\
\text { poultry and white meat, dairy products, margarine or butter in cooking/table, sausages, fried food, grilled meat or fish }\end{array}$ \\
\hline Pot et al. & $\begin{array}{l}\text { Healthy: } 1 \text { st dietary pattern }(2) \text { - cheese, crisps, savory snacks, fresh fruit, legumes, low fat milk, } \\
\text { nuts and seeds, other fruits } \\
\text { Unhealthy: None } \\
\text { Other: None }\end{array}$ \\
\hline Ryswyk et al. & $\begin{array}{l}\text { Healthy: Healthy (2)- Smoked/Dried Fish, Mix dish/beef/pork, vegetables, lentils, chicken, soup } \\
\text { Unhealthy: Western (-4)- Processed meat, bakery items, fried foods (fries, chips), ice-cream, candy, eggs, white bread, cake } \\
\text { Other: Vitamin (0)-Vitamin E, B-complex vitamins, Vitamin C, Zinc, Beta-carotene, Vitamin A, } \\
\text { Selenium, Calcium, multi-vitamin, Iron }\end{array}$ \\
\hline Shin et al. & $\begin{array}{l}\text { Healthy: Prudent (4)- vegetables, fruits, soy, potatoes, seaweed, mushroom, fish } \\
\text { Unhealthy: Western (-4)- bread, meat, processed meats, dairy, soup, coffee, soft drinks, } \\
\text { black tea, sauces, mayonnaise and dressing } \\
\text { Other: Traditional (1)- salmon, seafood other than fish, oily fish, lean fish, salty fish, chicken and pickles }\end{array}$ \\
\hline Tiznobeyk et al. & $\begin{array}{l}\text { Healthy: Healthy (5)- fish, poultry, eggs, low-fat dairy products, vegetables, legumes, nuts and seeds, } \\
\text { whole grains, mayonnaise, fruits, dried fruits and fruit juices } \\
\text { Unhealthy: Unhealthy (-4)- red meats organ and processed meats, high-fat dairy products, pickles } \\
\text { (in vinegar or brine), sweets and desserts, sugars and soda, tea and coffee, animal and solid fats and salted snacks }\end{array}$ \\
\hline Tumas et al. & $\begin{array}{l}\text { Healthy: Prudent (4)- non-starchy vegetables, fruits, pulses, lean meat } \\
\text { Unhealthy: Traditional (-2)- fat meat, bakery products, vegetable oils and mayonnaise, starchy vegetables } \\
\text { Other: Rural (-1)- processed meat, pulses, starchy vegetables, bakery products, candies, added sugars; } \\
\text { Starchy (-1)- refined grains, whole grains, eggs, added sugars }\end{array}$ \\
\hline Wu et al. & $\begin{array}{l}\text { Healthy: Pickle-vegetable (2) - tea, fruits, vegetables, fermentation food, pickles } \\
\text { Unhealthy: Sugar-Fried Foods (-2)- Milk, Fried Foods, Sweets } \\
\text { Other: Soy (1)- mushrooms, soybeans, milk, dried tofu; Coffee-Egg (0)- eggs, coffee, sugar, fresh fruit juice; } \\
\text { Meat-fat (1)- livestock, seafood, poultry, shellfish, processed meat, fish (sashimi), } \\
\text { meat (streaky, organ, and smoked), and milk }\end{array}$ \\
\hline
\end{tabular}




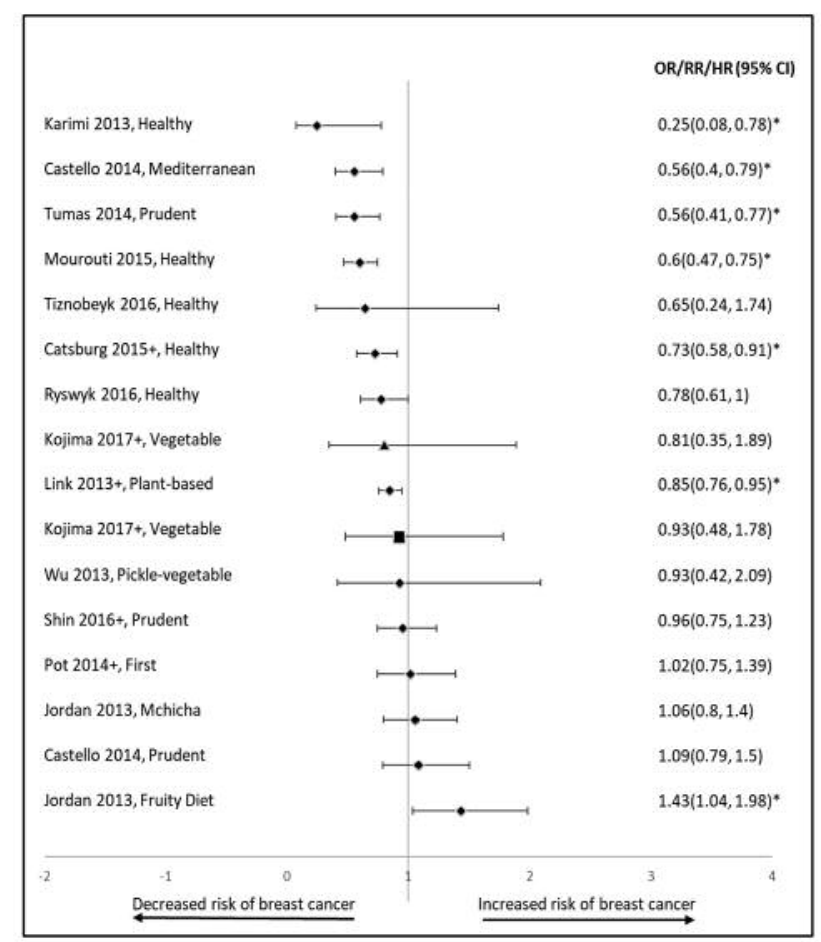

+: Nested case control study; ": Significant outcome; $\boldsymbol{\Lambda}$ : Pre-menopausal women; $\mathbf{E}$ Post-menopausal women; : All women

OR: Odds ratio; RR: relative risk; HR: hazards ratio; $\mathrm{Cl}$ : confidence interval.

Figure 2. Forest plot of risk estimates for comparisons of highest versus lowest categories of healthy dietary pattern intake (posteriori approach) and breast cancer.

dietary patterns met our ACS-derived criteria of "healthy". Of these, six were significantly associated with a lower breast cancer risk $(43,44,47,50,52,56)$. Null findings were reported in eight studies including the Kojima study, with risk estimates favoring a slightly lower breast cancer risk in six $(48,54,55,57,58)$ and three favoring a slightly greater risk $(43,46)$.

Jordan et al. found a significant positive association between a healthy dietary pattern and breast cancer risk (46). Common across the healthy dietary patterns significantly associated with reduced breast cancer risk was the inclusion of vegetables (Table IV). The one study that showed a positive association between a healthy dietary pattern and breast cancer risk did not include vegetables. Fruits, legumes, lean protein (fish, lean meat, low fat dairy) and whole grains were included in some, but not all, of the healthy dietary patterns significantly associated with reduced breast cancer risk.

Posteriori/Exploratory approach: Unhealthy dietary pattern. Forest plots of risk estimates regarding unhealthy dietary patterns and breast cancer are shown in Figure 3. A total of

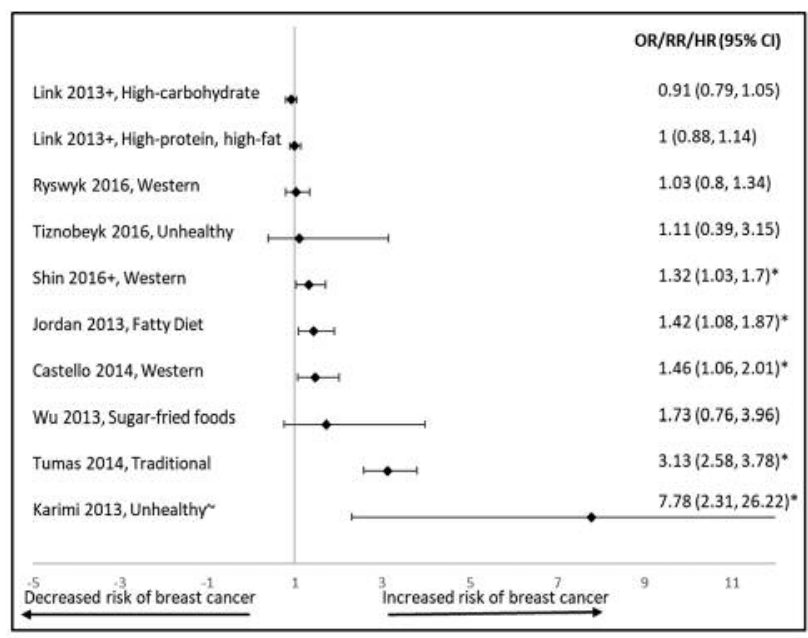

- The confidence interval has been shortened for representation

+: Nested case control study; ${ }^{*}$ : Significant outcome; $\boldsymbol{\Delta}$ : Pre-menopausal women; $\mathbf{\square}$ : Post-menopausal women; : All women

OR: Odds ratio; RR: relative risk; $\mathrm{HR}$ : hazards ratio; $\mathrm{Cl}$ : confidence interval.

Figure 3. Forest plot of risk estimates for comparison of highest versus lowest categories of unhealthy dietary pattern intake (posteriori approach) and breast cancer.

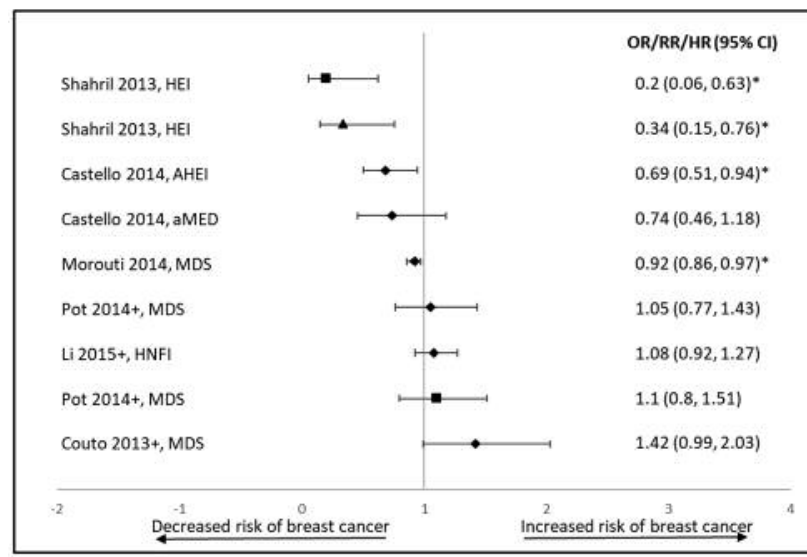

+: Nested case control study; *: Significant outcome; $\mathbf{A}$ : Pre-menopausal women; $\mathbf{E}$ : Post-menopausal women; : All women

HEI: Healthy Eating Index; AHEI: Alternate Healthy Eating Index; aMED: Alternate Mediterranean Diet Score; MDS: Mediterranean Diet Score; HNFI: Healthy Nordic Food Index; OR: odds ratio; RR: relative risk; $\mathrm{HR}$ : hazards ratio; $\mathrm{Cl}$ : confidence interval.

Figure 4. Forest plot of risk estimates of adherence to different dietary patterns recommended by established dietary guidelines (a priori approach) and breast cancer.

ten dietary patterns met our ACS-derived criteria for "unhealthy" (two nested case-control studies and seven casecontrol studies). Of these, five were significantly associated 
Table IV. Characterization of Healthy dietary patterns based on American Cancer Society (ACS) dietary guidelines for cancer protective food groups.

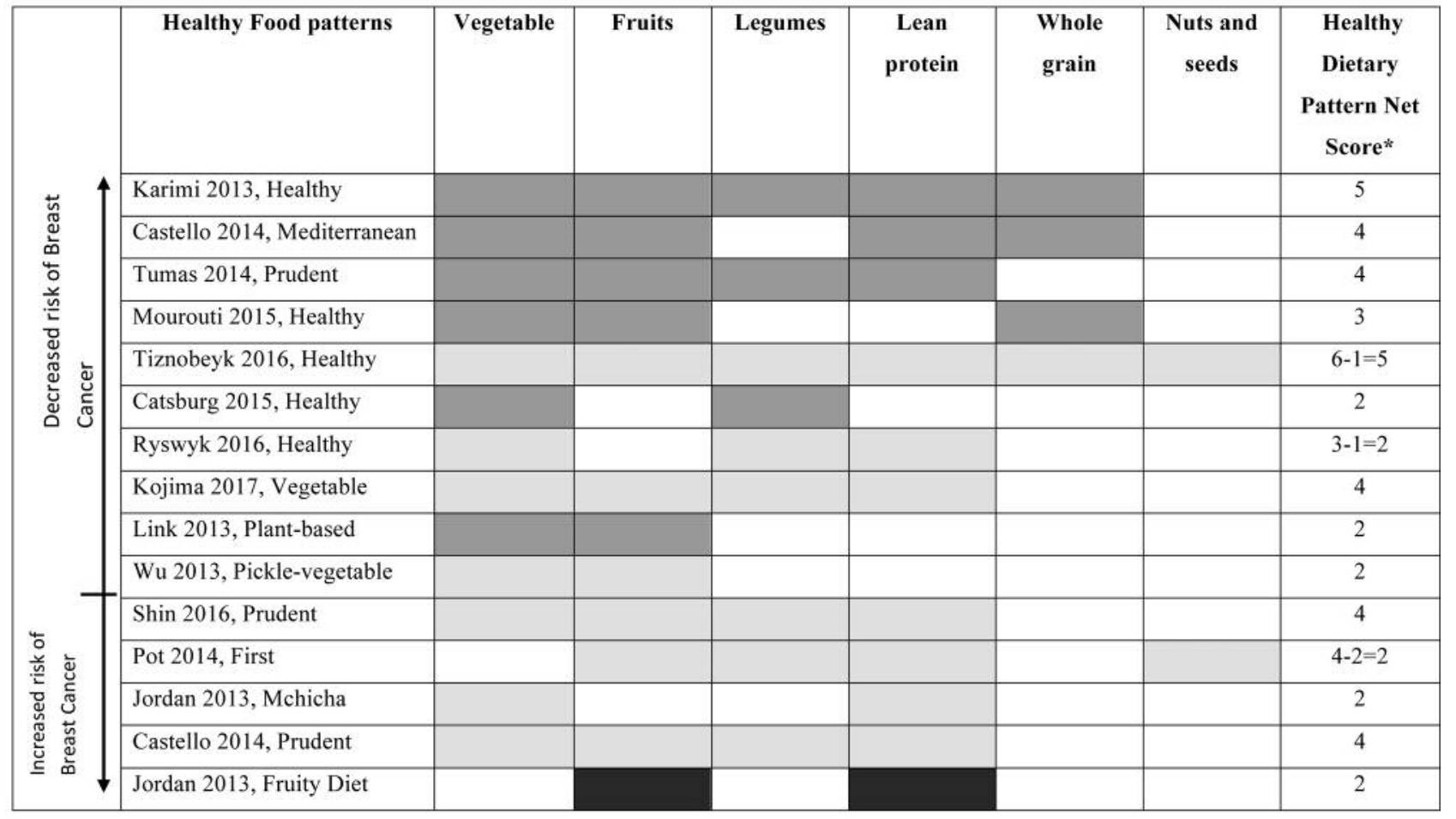

Shaded boxes denote cancer protective foods included in the healthy dietary pattern. Dark grey: Study reported significantly decreased risk of breast cancer; light grey: study reported non-significant association with breast cancer; black: study reported significantly increased risk of breast cancer; *Healthy Dietary Pattern Net Score was calculated as follows: for a given dietary pattern, +1 point was awarded each time one of the six ACAdesignated healthy (cancer protective) food groups was represented in the explanation of the dietary pattern and -1 point was assigned each time one of the six ACA-designated unhealthy (cancer promoting) food groups was represented in the explanation of the dietary pattern (Table III).

with greater risk of breast cancer $(46,47,50,54,56)$. Null findings were reported in five studies, with risk estimates favoring a slightly greater risk of unhealthy dietary patterns in three $(52,55,57)$, and slightly lower risk in one study (50). One study showed no association between an unhealthy dietary pattern and breast cancer risk (50).

The common food components/food groups represented across all the unhealthy dietary patterns significantly associated with an increased risk of breast cancer were saturated fats and red and processed meats (Table V). Sugar sweetened beverages and candy, refined grains, and fried foods were included in some, but not all, of the unhealthy dietary patterns significantly associated with increased breast cancer risk.

A priori/Hypothesis-oriented approach. Six studies (three nested case-control studies and three case-control studies), characterizing five dietary indices determined a priori, evaluated the association between adherence to dietary patterns recommended by established dietary guidelines and breast cancer risk (Figure 4). Two studies showed adherence to the Healthy Eating Index or Alternative Healthy Eating Index related to lower breast cancer risk $(42,43)$. One of these studies, by Shahril et al. (42), showed a favorable relationship between Healthy Eating Index adherence and lowered breast cancer risk in both pre- and post-menopausal women. Adherence to a Mediterranean-type diet was also significantly associated with lower breast cancer risk in one study that evaluated adherence using Mediterranean Diet Score $(51)$, but not others using this index $(45,53)$ or the alternative Mediterranean Diet Score (43). One study evaluating diet quality using the Healthy Nordic Food Index found no association between adherence to this index and breast cancer risk (49).

Star-rating of exposure. The results of the star-rating for the dietary assessment approaches used in the included studies are shown in Table VI (posteriori, and, a priori). Eleven of the studies included scored 3 or 4 stars, indicating high quality for the dietary assessment approach used. All of the studies included, used a validated FFQ for the population studied except for Pot et al. (53), who used a 4 to 7-day food dairy. 
Table V. Characterization of Unhealthy dietary patterns based on American Cancer Society (ACS) dietary guidelines for cancer promoting food groups.

\begin{tabular}{|c|c|c|c|c|c|c|c|c|}
\hline \multirow{2}{*}{ 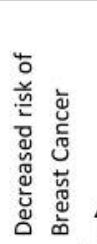 } & Unhealthy Food Patterns & $\begin{array}{c}\text { Sugar } \\
\text { sweetened } \\
\text { beverages } \\
\text { and candy }\end{array}$ & $\begin{array}{c}\text { Saturated } \\
\text { fats }\end{array}$ & $\begin{array}{c}\text { Red and } \\
\text { processed } \\
\text { meats }\end{array}$ & $\begin{array}{l}\text { Fried } \\
\text { foods }\end{array}$ & $\begin{array}{c}\text { Refined } \\
\text { grains }\end{array}$ & Alcohol & $\begin{array}{c}\text { Unhealthy } \\
\text { Dietary } \\
\text { Pattern } \\
\text { Net Score* }\end{array}$ \\
\hline & Link 2013, High-carb & & & & & & & -2 \\
\hline \multirow{9}{*}{ 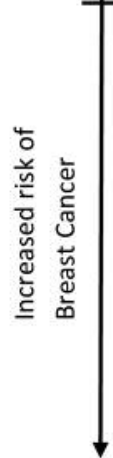 } & Link 2013, High-Protein \& fat & & & & & & & -2 \\
\hline & Ryswyk 2016, Western & & & & & & & -4 \\
\hline & Tiznobeyk 2016, Unhealthy & & & & & & & -4 \\
\hline & Shin 2016, Western & & & & & & & -4 \\
\hline & Jordan 2013, Fatty Diet & & & & & & & -2 \\
\hline & Castello 2014, Western & & & & & & & -4 \\
\hline & Wu 2013, Sugar-Fried Foods & & & & & & & -2 \\
\hline & Tumas 2014, Traditional & & & & & & & -2 \\
\hline & Karimi 2013, Unhealthy & & & & & & & $-5+1=-4$ \\
\hline
\end{tabular}

Shaded boxes denote cancer promoting foods included in the unhealthy dietary pattern. light grey: Study reported non-significant association with breast cancer; black: study reported significantly increased risk of breast cancer. *Unhealthy Dietary Pattern Net Score was calculated as follows: for a given dietary pattern, -1 point was awarded each time one of the six ACA-designated unhealthy (cancer promoting) food groups was represented in the explanation of the dietary pattern and +1 point was assigned each time one of the six ACA-designated healthy (cancer protecting) food groups was represented in the explanation of the dietary pattern (Table III).

The FFQs typically assessed intake over the past year in the studies that were included. Six out of sixteen papers didn't provide information about the reproducibility of the FFQ used; Pot et al. (53) did not mention whether the food diary approach used was assessed for reproducibility. Out of the thirteen posteriori studies, three used factor loadings less than 0.3 to characterize dietary patterns; all the a priori studies used a dietary index that was validated in the population studied to determine adherence to the pre-determined dietary pattern. All included studies collected the dietary intake data once except Shin et al. (54) who collected these data twice.

Bias. Selection bias: Four of the seven nested case-control studies, and all ten of the case-control studies age-matched the controls with the cases. The other common factors considered for matching were location [Castello et al. (43), Jordan et al. (46), Morouti et al. (52), Tumas et al. (56), Couto et al. (45), and Morouti et al. (51)], history of cancer [Kojima et al. (48), Link et al. (50), Shin et al. (54), Wu et al. (58), Li et al. (49), Shahril et al. (42), and Pot et al. (53)], menopause status [Tiznobeyk et al.(55)], and calorie intake [Li et al. (49), Shin et al. (54), and Link et al. (50)].

Recall bias: All the case-control studies asked the cases to report their dietary intake in the 12 months (or more) prior to their breast cancer diagnosis and representing the past 12 months (or more) prior to recruitment for the controls. The exceptions were Karimi et al. (47), Morouti et al. (51), and Morouti et al. (52) where recall was based on 5-6 months prior to breast cancer diagnosis or recruitment. The dietary intake in the nested case-control studies was assessed at baseline and based on the previous 6 months to 1 year prior to recruitment. Cohorts were followed up for a time ranging from 1 year to 17 years.

Confounding: Important potential confounding variables include age, physical activity, BMI, smoking status and alcohol intake, as all are strongly associated with both breast cancer diagnosis and dietary quality. Castello et al. (43), Kojima et al. (48), and Shahril et al. (42) controlled for all 5 of these potential confounders. All studies controlled for age either through their selection criteria or statistical adjustment, but adjustment for physical activity, BMI, smoking status, and alcohol intake varied and are shown in Table VI.

\section{Discussion}

This is the first systematic review that scored published dietary patterns, based on established guidelines for reducing cancer risk. According to our ACS-derived dietary scoring method, "healthy" dietary patterns were significantly associated with lowered breast cancer risk in 6 of 15 comparisons. Most of the null association of healthy dietary patterns and breast cancer risk also tended to favor lowered 
Table VI. Potential confounding variables controlled for in studies on dietary patterns and breast cancer risk and the star-rating for the assessment of exposure for studies meeting inclusion criteria and using posteriori and an a priori approach.

\begin{tabular}{|c|c|c|c|c|c|c|c|c|c|c|}
\hline Reference & Age & $\begin{array}{l}\text { Body } \\
\text { mass } \\
\text { index }\end{array}$ & $\begin{array}{l}\text { Physical } \\
\text { activity }\end{array}$ & $\begin{array}{c}\text { Smoking } \\
\text { status }\end{array}$ & Alcohol & $\begin{array}{c}\text { Use of } \\
\text { validated } \\
\text { dietary } \\
\text { assessment } \\
\text { tool }\end{array}$ & $\begin{array}{c}\text { Use of } \\
\text { reproducible } \\
\text { dietary } \\
\text { assessment } \\
\text { tool }\end{array}$ & $\begin{array}{c}\text { Use of } \\
\text { appropriate } \\
\text { factor loadings } \\
(\geq 0.3) / \text { scoring } \\
\text { criteria }\end{array}$ & $\begin{array}{c}\text { Number } \\
\text { of times } \\
\text { data } \\
\text { collected }\end{array}$ & $\begin{array}{c}\text { Star } \\
\text { Rating }\end{array}$ \\
\hline Castello et al. & & & & & & Yes & Yes & Yes & Once & **** \\
\hline Catsburg et al. & & & & & & Yes & Yes & Yes & Once & $* * *$ \\
\hline Jordan et al. & & & & & & Yes & Yes & Yes & Once & **** \\
\hline Karimi et al. & & & & & & Yes & Yes & Yes & Once & $* * *$ \\
\hline Kojima et al. & & & & & & Yes & Yes & Yes & Once & *** \\
\hline Link et al. & & & & & & Yes & Yes & Yes & Once & $* * *$ \\
\hline Mourouti et al. & & & & & & Yes & Yes & Yes & Once & $* * *$ \\
\hline Pot et al. & & & & & & No & No & $\mathrm{No} / \mathrm{Yes}$ & Once & - /* $^{*}$ \\
\hline Ryswyk et al. & & & & & & Yes & No & Yes & Once & ** \\
\hline Shin et al. & & & & & & Yes & Yes & Yes & Multiple & $* * * *$ \\
\hline Tiznobeyk et al. & & & & & & Yes & Yes & No & Once & $* *$ \\
\hline Tumas et al. & & & & & & Yes & Yes & Yes & Once & $* * *$ \\
\hline Wu et al. & & & & & & Yes & No & No & Once & $*$ \\
\hline Couto et al. & & & & & & Yes & No & Yes & Once & $* *$ \\
\hline Li et al. & & & & & & Yes & No & Yes & Once & $* *$ \\
\hline Morouti et al. & & & & & & Yes & Yes & Yes & Once & $* * *$ \\
\hline Shahril et al. & & & & & & Yes & No & Yes & Once & $* *$ \\
\hline
\end{tabular}

Shaded boxes denote the confounders that have been controlled for in the studies; $\sim$ denotes the study that obtained 0 stars for the posteriori approach while it received $1 *$ for the a priori approach.

risk. Dietary patterns characterized as "unhealthy" were significantly associated with greater breast cancer risk in 5 of 10 comparisons. Null associations of unhealthy dietary patterns and breast cancer risk also tended to favor greater risk in most of the studies. Vegetables, as a food group, were common among all 6 of the healthy dietary patterns significantly associated with lower breast cancer risk, while saturated fat and red/processed meat were common among all 5 of the unhealthy dietary patterns that were significantly associated with greater breast cancer risk. Our findings most strongly support ACS dietary recommendations to include vegetables at every meal and snack and to limit intake of red and processed meats for lowering breast cancer risk.

Studies with the strongest design for the posteriori approach were Kojima et al. (48), Shin et al. (54), Karimi et al. (47) and Castello et al. (43); based on dietary assessment quality, control selection, confounding adjustments, and power of the study. The two largest studies, Kojima et al. (48) and Shin et al. (54) were conducted in Japan. While findings generally support breast cancer protective dietary patterns to be those that include 
vegetables and whole foods in their unprocessed form, the "Prudent" dietary pattern identified by Shin et al. (54) was not related to lowered breast cancer risk. Reasons for this finding are unclear, however, it should be noted that the traditional Japanese dietary pattern contains many of the ACS recommended foods for cancer prevention including fish and soy.

The "healthy" diet characterized by Karimi et al. (47) had a broader array of whole foods and scored the maximum 5 on the healthy dietary pattern net score derived using the ACS guidelines. This pattern included vegetables, fruits, low-fat dairy products, legumes including soy, olive and vegetable oils, fish, organ meat, poultry, pickles, and whole grains. The highest tertile of this healthy dietary pattern was associated with a $75 \%$ reduced risk of breast cancer compared to the lowest tertile $(p=0.02)$. This study was awarded three out of five stars for the assessment of exposure and controlled for all five of the potential confounders. These researchers mentioned that their study was adequately powered albeit, the numbers are low i.e. 100 cases and 174 controls; they also addressed most criteria for selection bias.

The "Mediterranean" diet characterized by Castello et al (43) was associated with $46 \%$ lower odds of developing breast cancer and was comprised of fish, vegetables, legumes, boiled potatoes, fruits, olives and vegetable oil. This pattern received a score of 4 on the ACS-derived dietary pattern score and controlled for all five of the potential confounders. The sample size of this study was over 1,000 cases and controls, and most criteria were met for selection bias. This study identified another healthy dietary pattern coined the "prudent" dietary pattern, which was high in low-fat dairy products, vegetables, fruits, and whole grains. This pattern also contained juices, which is notable because this pattern was not associated with a lower breast cancer risk. It is not clear why one healthy pattern in the Castello et al. (43) study over another was more closely associated with breast health. A potential reason could be attributed to the high fruit and juice content of the diet. A very high intake of fruit and juice has been associated with increased insulin levels, which may contribute to the promotion of tumor growth (59) via DNA synthesis altering the hormonal environment and inhibiting apoptosis (60). In support of this hypothesis, the healthy diet termed "fruity" diet, characterized by Jordan et al. (46), comprised of fish, mango, papaya, avocado and watery fruits, was related to greater breast cancer risk. This was the only study that showed a significant increase in the risk of breast cancer by adherence to a healthy pattern that included fruit. It is also important to note that this dietary pattern did not contain any vegetables.

A commonality across cancer protective dietary patterns was the inclusion of vegetables. The protective effect of vegetables may be due to the phytonutrient content. These compounds, found in fruits and vegetables, include antioxidants, phytosterols, and flavonoids which help to prevent oxidative damage to cells (61). Fruits and vegetables are also rich in fiber which binds estrogens during enterohepatic circulation (62). These compounds can inhibit metastasis and protein kinase activity, exhibit antiproliferative properties and induce apoptosis, thus reducing cancer progression and development. Also, higher intake of fruits and vegetables could be associated with other lifestyle factors such as lower intake of alcohol and dietary fat, lower rates of obesity, higher physical activity (63).

In contrast to cancer protective dietary patterns, those that were found to be associated with a greater risk of breast cancer contained fatty foods and more processed fare. Whether the type of fat or the absolute quantity of fat is more highly related to cancer risk cannot be parceled out from this type of investigation. What is clear, however, is that major food sources of saturated fat were foods common among cancer promoting dietary patterns. Biologically, dietary fats can influence the process of carcinogenesis by modulating intracellular signaling cascades (64).

Patterns that tended to reflect a more Westernized type of diet were consistently related to greater breast cancer risk. The "unhealthy" dietary pattern with the greatest odds of developing breast cancer was characterized by Karimi et al. (47) (OR [95\%CI]) and included soft drinks, sugars, tea and coffee, French fries, chips, salt, sweets and desserts, hydrogenated fats, nuts, refined grains, red and processed meat, and processed fruit juice. It scored -4 using our scoring matrix.

The "western" dietary pattern by Castello et al. (43) was characterized by high-fat dairy products, processed meat, refined grains, sweets, caloric drinks and other convenience foods and sauces. This dietary pattern received a score of -4 on the unhealthy dietary pattern net score derived using the ACS dietary guidelines. Notably, the "Western" dietary pattern by Shin et al. (54) composed of bread, meat, processed meat, dairy, soup, coffee, soft drinks, tea, sauces, mayonnaise and dressing contributed to a significant increase in the risk of breast cancer among women in Japan.

The study with the strongest design for the a priori approach based on our star rating, bias assessment, and adjustment for key confounders was that conducted by Castello et al. (43). These researchers assessed diets using the Alternate Healthy Eating Index and found a 31\% lower risk of breast cancer with greater adherence, especially in the case of women with triple negative breast cancers. Consistent with the findings of the posteriori analyses, these findings suggest that dietary patterns high in fruits, vegetables, whole grains, and limited in red meats, saturated fat and sodium are associated with lower risk of breast cancer.

The results of the present study support those from two previously published systematic reviews and meta-analyses on this topic $(18,19)$. The review by Brennan et al. (18) was performed on 16 studies that were published from 2001-2009. Albuquerque et al. (19) carried out their systematic review on 26 studies that were published up to December 2012. Both 
reviews were limited to studies that used posteriori approach to define dietary patterns and showed a possible inverse association between healthy diets (rich in vegetables, fruits, fish, poultry, legumes, low fat dairy) and risks of breast cancer.

Our systematic review is not without limitations. Heterogeneity among the factor loadings in the dietary patterns determined by the posteriori analyses made the comparison of the dietary patterns across studies challenging. This limitation was addressed by developing a scoring matrix based on the recommendations of the ACS. Lack of a standardized method of data collection is another limitation. For example, not all FFQs accounted for seasonality or portion size, the numbers of questions within each FFQ varied, and seven studies failed to use a validated FFQ, all which may lead to an underrepresentation or overrepresentation of certain food groups. Furthermore, the temporal window during which data were collected is inconsistent among studies and ranged between 4-7 days when using a food diary and the previous 5 years to 6 months before diagnosis.

The major strength of this systematic review is the use of an ACS-based scoring matrix to confirm healthy and the unhealthy dietary patterns reported in the original studies. To our knowledge, this is the first systematic review on this topic to use this approach to determine whether the reported dietary pattern (posteriori approach) was healthy or unhealthy based on established cancer guidelines. This study is also the first to systematically evaluate the posteriori as well as the a priori approaches in the same review. In addition, the study used the most recently published articles and was built upon previous reviews.

In conclusion, the results provide evidence that dietary patterns that include vegetables as well as fruits, legumes, lean protein and whole grains may contribute to a reduction in the risk of breast cancer. Dietary patterns high in saturated fats and red and processed meats as well as added sugars, fried foods and refined grains may be breast cancer promoting. Prospective studies that include the collection of dietary data multiple times over the period of follow-up while using validated and reproducible FFQs should be carried out in the future to better inform the relationship between dietary pattern and breast cancer risk.

\section{Conflicts of Interest}

The Authors declare no conflict of interest and this systematic review was conducted as a part of a master's thesis.

\section{References}

1 U.S. Cancer Statistics Working Group. United States Cancer Statistics: 1999-2014 Incidence and Mortality Web-based Report. Atlanta: U.S. Department of Health and Human Services, Centers for Disease Control and Prevention and National Cancer Institute; 2017. Available at: www.cdc.gov/uscs.
2 Peter Boyle and Bernard Levin: World cancer report 2008. International Agency for Research on Cancer, 2008.

3 Torre LA, Bray F, Siegel RL, Ferlay J, Lortet-Tieulent J and Jemal A: Global cancer statistics. Cancer J Clin 65: 87-108, 2015.

4 Danaei G, Vander Hoorn S, Lopez AD, Murray CJ and Ezzati M: Causes of cancer in the world: comparative risk assessment of nine behavioural and environmental risk factors. Lancet 366 : 1784-1793, 2005.

5 Hauner $\mathrm{H}$ and Hauner $\mathrm{D}$ : The impact of nutrition on the development and prognosis of breast cancer. Breast Care 5(6): 377-381, 2010.

6 Michels KB, Mohllajee AP, Roset-Bahmanyar E, Beehler GP and Moysich: Diet and breast cancer. Cancer 109: 2712-2749, 2007.

7 Smith-Warner SA, Spiegelman D, Yaun S, Adami H, Beeson WL, van den Brandt PA, Folsom AR, Fraser GE, Freudenheim JL, Goldbohm RA, Graham S, Miller AB, Potter JD, Rohan TE, Speizer FE, Toniolo P, Willett WC, Wolk A, Zeleniuch-Jacquotte A and Hunter DJ: Intake of Fruits and Vegetables and Risk of Breast Cancer a Pooled Analysis of Cohort Studies. JAMA 285(6): 769-776, 2001.

8 Howe GR, Hirohata T, Hislop TG, Iscovich JM, Yuan JM, Katsouyanni K, Lubin F, Marubini E, Modan B, Rohan T, Toniolo P and Shunzhang Y: Dietary factors and risk of breast cancer: Combined analysis of 12 case - control studies. J Natl Cancer Inst 82(7): 561-569, 1990.

9 Gandini S, Merzenich H, Robertson C and Boyle P: Metaanalysis of studies on breast cancer risk and diet: the role of fruit and vegetable consumption and the intake of associated micronutrients. Eur J Cancer 36: 636-646, 2000.

10 Freudenheim JL, Marshall JR, Vena JE, Laughlin R, Brasure JR, Swanson MK, Nemoto T and Graham S: Premenopausal breast cancer risk and intake of vegetables, fruits, and related nutrients. J Natl Cancer Inst 8: 340-348, 1996.

11 Flower G, Fritz H, Balneaves LG, Verma S, Skidmore B, Fernandes R, Kennedy D, Cooley K, Wong R, Sagar S, Fergusson D and Seely D: Flax and breast cancer: A systematic review. Integr Cancer Ther 13(3): 181-192, 2014.

$12 \mathrm{Wu}$ J, Zeng R, Huang J, Li X, Zhang J, Ho JC and Zheng Y: Dietary protein sources and incidence of breast cancer: A doseresponse meta-analysis of prospective studies. Nutrients $8(11)$ : $730,2016$.

13 Kushi LH, Doyle C, McCullough M, Rock CL, DemarkWahnefried W, Bandera EV, Gapstur S, Patel AV, Andrews K and Gansler T; American Cancer Society 2010 Nutrition and Physical Activity Guidelines Advisory Committee: American cancer society guidelines on nutrition and physical activity for cancer prevention. CA Cancer J for Clin 62(1): 30-67, 2012.

14 Edefonti V, Randi G, Vecchia CL, Ferraroni M and Decarli A: Dietary patterns and breast cancer: a review with focus on methodological issues. Nutr Rev 67(6): 297-314, 2009.

15 Johnson RA and Wichern DW: Applied Multivariate statistical analysis. Upper Saddle River, NJ, Prentice-Hall, 2002.

16 U.S. Department of Agriculture and U.S. Department of Health and Human Services. Dietary Guidelines for Americans. 7th Edition, Washington, DC: U.S. Government Printing Office, 2010.

17 Glade MJ: Food, Nutrition, Physical Activity and the Prevention of Cancer: A Global Perspective. Nutrition 15(6): 523-526, 1999.

18 Brennan SF, Cantwell MM, Cardwell CR, Velentzis LS and Woodside JV: Dietary patterns and breast cancer risk: A systematic review and meta-analysis. AJCN 91(5): 1294-1302, 2010. 
19 Albuquerque CR, Baltar VT and Marchioni DM: Breast cancer and dietary patterns: A systematic review. Nutr Rev 72(1): 1-17, 2014.

20 Liberati A, Altman DG, Tetzlaff J, Mulrow C, Gøtzsche PC, Ioannidis JPA and Moher D: The PRISMA statement for reporting systematic reviews and meta-analyses of studies that evaluate healthcare interventions: explanation and elaboration. The BMJ 339: b2700, 2009.

21 Ruffin MT, August DA, Kelloff GJ, Boone CW, Weber BL and Brenner DE: Selection criteria for breast cancer chemoprevention subjects. J Cell Biochem 53: 234-241, 1993.

22 Lewallen S and Courtright P: Epidemiology in Practice: CaseControl Studies. Community Eye Health 11(28): 57-58, 1998.

23 Breslow NE and Day NE: Statistical Methods in Cancer Research-The Analysis of Case-Control Studies. Lyon (France): International Agency for Research on Cancer, 1, CH III, 1980.

24 Castello A, Ascunce N, Salas-Trejo D, Vidal C, SanchezContador C, Santamarina C, Pedraz-Pingarrón C, Moreno MP, Pérez-Gómez B, Lope V, Aragonés N, Vioque J and Pollán M: Association between western and Mediterranean dietary patterns and mammographic density. OB/GYN 128(3): 574-581, 2016

25 Castelló A, Buijsse B, Sánchez-Contador C, Santamariña C, Pedraz-Pingarrón $\mathrm{C}$ and Moreo P: Dietary patterns and mammographic breast density in Spanish women: Crosssectional DDM study. Ann Nutr Metab 62: e59, 2013.

26 Voevodina O, Billich C, Arand B and Nagel G: Association of Mediterranean diet, dietary supplements and alcohol consumption with breast density among women in south Germany: A crosssectional study. BMC Public Health 13: e203, 2013.

27 Kruk J and Marchlewicz M: Dietary fat and physical activity in relation to breast cancer among polish women. Asian Pac J of Cancer Prev 14(4): 2495-2502, 2013

28 Llanos AA, Krok JL, Peng J, Pennell ML, Olivo-Marston S, Vitolins $\mathrm{M} \mathrm{Z}$ and Paskett ED: Favorable effects of low-fat and low-carbohydrate dietary patterns on serum leptin, but not adiponectin, among overweight and obese premenopausal women: a randomized trial. SpringerPlus 3: 175, 2014.

29 Ahmadnia Z, Joukar F, Hasavari F, Roushan ZA and Khalili M: Dietary patterns and risk of breast cancer in women in Guilan province, Iran. Asian Pac J of Cancer Prev 17(4): 2035-2040, 2016.

30 Assi N, Moskal A, Slimani N, Viallon V, Chajes V, Freisling H, Monni S, Knueppel S, Förster J, Weiderpass E, Lujan-Barroso L, Amiano P, Ardanaz E, Molina-Montes E, Salmerón D, Quirós JR, Olsen A, Tjønneland A, Dahm CC, Overvad K, Dossus L, Fournier A, Baglietto L, Fortner RT, Kaaks R, Trichopoulou A, Bamia C, Orfanos P, De Magistris MS, Masala G, Agnoli C, Ricceri F, Tumino R, Bueno de Mesquita HB, Bakker MF, Peeters PH, Skeie G, Braaten T, Winkvist A, Johansson I, Khaw KT, Wareham NJ, Key T, Travis R, Schmidt JA, Merritt MA, Riboli E, Romieu I and Ferrari P: A treelet transform analysis to relate nutrient patterns to the risk of hormonal receptor-defined breast cancer in the European prospective investigation into cancer and nutrition (EPIC). Public Health Nutr 19(2): 242-254, 2016.

31 Penniecook-Sawyers JA, Jaceldo-Siegl K, Fan J, Beeson L, Knutsen S, Herring P and Fraser GE: Vegetarian dietary patterns and the risk of breast cancer in a low-risk population. Br J Nutr 115(10): 1790-1797, 2016.

32 Harris HR, Bergkvist L and Wolk A: An estrogen-associated dietary pattern and breast cancer risk in the Swedish mammography cohort. Int J Cancer 137(9): 2149-2154, 2015.
33 Hirko KA, Spiegelman D, Barnett JB, Cho E, Willett WC, Hankinson SE and Eliassen AH: Dietary patterns and plasma sex hormones, prolactin, and sex hormone-binding globulin in premenopausal women. Cancer Epidemiol Biomarkers Prev 25(5): 791-798, 2016.

34 Sánchez-Zamorano LM, Flores-Luna L, Angeles-Llerenas A, Ortega-Olvera C, Lazcano-Ponce E, Romieu I, MaineroRatchelous F and Torres-Mejía G: The western dietary pattern is associated with increased serum concentrations of free estradiol in postmenopausal women: Implications for breast cancer prevention. Nutr Res 36(8): 845-854, 2016.

35 Harris HR, Willett WC, Vaidya RL and Michels KB: An adolescent and early adulthood dietary pattern associated with inflammation and the incidence of breast cancer. Cancer Res 77(5): 1179-1187, 2017.

36 Hidaka BH, Carlson SE, Kimler BF and Fabian CJ: Dietary associations with a breast cancer risk biomarker depend on menopause status. Nutr and Cancer 68(7): 1115-1122, 2016.

37 Hirko KA, Willett WC, Hankinson SE, Rosner BA, Beck AH, Tamimi RM and Eliassen AH: Healthy dietary patterns and risk of breast cancer by molecular subtype. Breast Cancer Res Treat 155(3): 579-588, 2016.

38 Kakkoura MG, Demetriou CA, Loizidou MA, Loucaides G, Neophytou I, Marcou Y, Hadjisavvas A and Kyriacou K: Singlenucleotide polymorphisms in one-carbon metabolism genes, Mediterranean diet and breast cancer risk: A case-control study in the Greek-Cypriot female population. Genes and Nutr 10(2): 1-11, 2015.

39 Kakkoura MG, Loizidou M A, Demetriou CA, Loucaides G, Daniel M, Kyriacou K and Hadjisavvas A: The synergistic effect between the Mediterranean diet and GSTP1 or NAT2 SNPs decreases breast cancer risk in Greek-Cypriot women. Eur J Nutr 56(2): 545-555, 2017.

40 Harris HR, Willett WC, Vaidya RL and Michels KB: Adolescent dietary patterns and premenopausal breast cancer incidence. Carcinogenesis 37(4): 376-384, 2016.

41 Hidaka BH, Kimler BF, Fabian CJ and Carlson SE: An empirically derived dietary pattern associated with breast cancer risk is validated in a nested case-control cohort from a randomized primary prevention trial. Clinical Nutrition ESPEN 17: 8-17, 2017.

42 Shahril MR, Sulaiman S, Shaharudin SH and Akmal SN: Healthy eating index and breast cancer risk among Malaysian women. ECP 22(4): 342-347, 2013.

43 Castello A, Pollan M, Buijsse B, Ruiz A, Casas AM, BaenaCanada JM, Lope V, Antolín S, Ramos M, Muñoz M, Lluch A, de Juan-Ferré A, Jara C, Jimeno MA, Rosado P, Díaz E, Guillem V, Carrasco E, Pérez-Gómez B, Vioque J, Boeing H, Martín M; GEICAM researchers: Spanish Mediterranean diet and other dietary patterns and breast cancer risk: Case-control EpiGEICAM study. Br J Cancer 111(7): 1454-1462, 2014.

44 Catsburg C, Kim RS, Kirsh VA, Soskolne CL, Kreiger N and Rohan TE: Dietary patterns and breast cancer risk: A study in 2 cohorts. AJCN 101(4): 817-823, 2015.

45 Couto E, Sandin S, Löf M, Ursin G, Adami HO and Weiderpass E: Mediterranean Dietary Pattern and Risk of Breast Cancer. PLoS ONE 8(2): e55374, 2013.

46 Jordan I, Hebestreit A, Swai B and Krawinkel MB: Dietary patterns and breast cancer risk among women in northern Tanzania: A case-control study. Eur J Nutr 52(3): 905-915, 2013. 
47 Karimi Z, Jessri M, Houshiar-Rad A, Mirzaei HR and Rashidkhani B: Dietary patterns and breast cancer risk among women. Public Health Nutr 17(5): 1098-1106, 2014.

48 Kojima R, Okada E, Ukawa S, Mori M, Wakai K, Date C, Iso $\mathrm{H}$ and Tamakoshi A: Dietary patterns and breast cancer risk in a prospective Japanese study. Breast Cancer 24(1): 152-160, 2017.

49 Li Y, Roswall N, Sandin S, Ström P, Adami H and Weiderpass, E: Adherence to a healthy nordic food index and breast cancer risk: Results from a Swedish cohort study. Cancer Causes and Control 26(6): 893-902, 2015.

50 Link LB, Canchola AJ, Bernstein L, Clarke CA, Stram DO, Ursin G and Horn-Ross PL: Dietary patterns and breast cancer risk in the California teachers study cohort. AJCN 98(6): 1524$1532,2013$.

51 Mourouti N, Kontogianni MD, Papavagelis C, Plytzanopoulou P, Vassilakou T, Malamos N, Linos A and Panagiotakos DB: Adherence to the Mediterranean diet is associated with lower likelihood of breast cancer: A case-control study. Nutr and Cancer 66(5): 810-817, 2014.

52 Mourouti N, Papavagelis C, Plytzanopoulou P, Kontogianni M, Vassilakou T, Malamos N, Linos A and Panagiotakos DB: Dietary patterns and breast cancer: A case-control study in women. Eur J Nutr 54(4): 609-617, 2015.

53 Pot GK, Stephen AM, Dahm CC, Key TJ, Cairns BJ, Burley VJ, Cade JE, Greenwood DC, Keogh RH, Bhaniani A, McTaggart A, Lentjes MA, Mishra G, Brunner EJ and Khaw KT: Dietary patterns derived with multiple methods from food diaries and breast cancer risk in the UK dietary cohort consortium. Eur J Nutr 68(12): 1353-1358, 2014.

54 Shin S, Saito E, Inoue M, Sawada N, Ishihara J, Takachi R, Nanri A, Shimazu T, Yamaji T, Iwasaki M, Sasazuki S and Tsugane S: Dietary pattern and breast cancer risk in Japanese women: The Japan public health center-based prospective study (JPHC study). Br J Nutr 115(10): 1769-1779, 2016.

55 Tiznobeyk Z, Sheikhi Mobarakeh Z, Qorbani M, Koohdani F, Sotoudeh G, Khajehnasiri F, Khosravi S and Doostan F: Dietary patterns and benign breast diseases: A case-control study. Br J Nutr 116(2): 353-359, 2016.
56 Tumas N, Niclis C, Aballay LR, Osella AR and Diaz MP: Traditional dietary pattern of South America is linked to breast cancer: An ongoing case-control study in Argentina. Eur J Nutr 53(2): 557-566, 2014.

57 Van Ryswyk K, Villeneuve PJ, Johnson KC and The Canadian Cancer Registries Epidemiology Research Group: Dietary patterns and the risk of female breast cancer among participants of the Canadian national enhanced cancer surveillance system. Can J Public Health 107(1): e49-55, 2016.

$58 \mathrm{Wu}$ J, Chang Y, Hou Y, Chiu W, Chen J, Chen S, Wu C, Chang $\mathrm{Y}$ and Chang Y: Meat-fat dietary pattern may increase the risk of breast cancer-A case-control study in Taiwan. Tzu Chi Med J 25(4): 233-238, 2013.

59 Gupta K, Krishnaswamy G, Karnad A and Peiris AN: Insulin: a novel factor in carcinogenesis. Am J Med Sci 323: 140-145, 2002.

60 Pollak M: Insulin and insulin-like growth factor signaling in neoplasia. Nat Rev Cancer 8: 915-928, 2008.

61 Steinmetz KA and Potter JD: Vegetables, fruit, and cancer prevention: A review. J Am Diet Assoc 96(10): 1027-1039, 2016.

62 Maskarinec G, Morimoto Y, Takata Y, Murphy SP and Stanczyk FZ: Alcohol and dietary fibre intakes affect circulating sex hormones among premenopausal women. Public Health Nutr 9(7): 875-881, 2006.

63 Aune D, Giovannucci E, Boffetta P, Fadnes LT, Keum N, Norat T, Greenwood DC, Riboli E, Vatten LJ and Tonstad S: Fruit and vegetable intake and the risk of cardiovascular disease, total cancer and all-cause mortality-a systematic review and doseresponse meta-analysis of prospective studies. Int J Epi 46(3): 1029-1056, 2017.

64 Rose DP: Effects of dietary fatty acids on breast and prostate cancers: Evidence from in vitro experiments and animal studies. AJCN 6: 1513S-1522S, 1997. 